\title{
Utvecklingen av interaktionell kompetens hos läkare som lär sig svenska
}

\author{
Mönster i frågesekvenser i rollspel med patienter
}

\author{
Av INGELA TYKESSON, LINDA KAHLIN \& MIHAELA \\ OANA ROMANITAN
}

\begin{abstract}
Tykesson, Ingela, ingela.tykesson@sh.se, Associate Professor, School of Culture and Education, Södertörn University; Kahlin, Linda, linda.kahlin@sh.se, Associate Professor, School of Culture and Education, Södertörn University; Romanitan, Mihaela Oana, mihaela.romanitan@ki.se, M.D., Ph.D., Department of Clinical Science and Education, Södersjukhuset (KI SÖS), S1: "The development of interactional competence of doctors learning Swedish. Patterns of question sequences in role-play with patients". Språk och stil NF 29, 2019, pp. 41-72.
\end{abstract}

County councils in Sweden annually engages foreign-educated doctors from other EU countries, to cover the shortage of doctors. This article examines a group of fourteen doctors that have been recruited from Eastern and Southern Europe to work in Sweden. It investigates the doctors' development of interactional competence during an intensive Swedish course conducted on a campus in Poland for 14 weeks. The investigation is conducted through role-plays in the form of medical consultations arranged on two occasions in the course, in the 6th and 12th weeks respectively. A total of 28 role-plays have been audio recorded and analysed using conversation analysis, CA. The main question is whether the participants' ability to respond to the patients' concerns advanced during the course.

The analysis shows that the doctors' ability to ask follow-up questions related to the patients' problem description improved on the second role-play occasion, as well as their ability to demonstrate their understanding of the patients' descriptions. There is also a tendency, the second time, for follow-up questions to lead to more fully developed responses from the patients. The result therefore indicates that the doctors' interactional competence increased during the course, despite the fact that the language teaching during the course is mainly based on written texts. In addition, a minor quantitative analysis indicates a faster talk rate, increased length of turns, and fewer hesitation marks during the second role-play.

Keywords: interactional competence, doctor-patient interaction, role-play, conversation analysis, second language learning, professional language, Swedish health care.

Det har länge varit brist på specialläkare i Sverige, och den fria rörligheten inom EU har ökat möjligheterna för landstingen att täcka denna brist genom att 
rekrytera utlandsutbildade läkare. ${ }^{1}$ Bristen på läkare inom många specialiteter verkar också komma att råda en lång tid framöver. Enligt en prognos fram till 2035 krävs en tillförsel av 500 utlandsutbildade läkare per år, om inte efterfrågan på läkare ska vara större än tillgången (Socialstyrelsen 2018a). ${ }^{2}$ Svensk sjukvård är således beroende av tillgången på utlandsutbildade läkare. Det handlar dels om svenskar som studerar till läkare utomlands, dels om läkare med ursprunglig hemvist $i$ andra länder, framför allt inom EU. Någon offentlig statistik över hur många från respektive grupp som beviljas läkarlegitimation varje år finns inte. ${ }^{3}$

Inom ett samtalsinriktat forskningsprojekt har vi följt en grupp läkare från Öst- och Sydeuropa på deras väg mot att etablera sig som specialister i Sverige. ${ }^{4}$ De har fătt anställning via ett företag som på landstingens uppdrag rekryterar läkare från olika EU-länder och ansvarar för deras undervisning i svenska. Undervisningen bedrivs på ett internat i Polen under fjorton veckor. Enligt rekryteringsföretagets webbsidor erbjuds språkträning inriktad på professionellt, medicinskt språk och typiska situationer som läkarna kan ställas inför i den nya arbetsmiljön. Särskild tonvikt läggs vid att förbereda läkarna för god kommunikation med patienter och kollegor, uppger man. I denna artikel intresserar vi oss för hur en sådan typ av språkutbildning utanför målspråksmiljön förbereder deltagarna för yrkesrelaterat samtalande.

För att läkare från EU-länder ska få svensk läkarlegitimation krävs språkkunskaper i svenska, danska eller norska (Socialstyrelsen 2018b), men något sådant språkkrav var inte aktuellt för EU-läkare fram till 2015, då datainsamlingen gjordes. Emellertid krävde de flesta landsting att dessa läkare skulle ha klarat språktester för att få anställning. I överenskommelsen med rekryteringsföretaget garanterades att läkarna skulle ha uppnått B1-nivå efter intensivkursen i Polen och B2-nivå efter ca tre månaders vistelse i Sverige, med hjälp av individuell undervisning på distans. ${ }^{5}$

\footnotetext{
${ }^{1}$ Av de läkarlegitimationer som utfärdades i Sverige 2014 gick $52 \%$ till läkare som utbildats i ett annat EU-land och 7 \% till läkare från »tredje land» (Socialstyrelsen 2015).

${ }^{2}$ Sedan 2003 har Socialstyrelsen utfärdat fler läkarlegitimationer till personer som studerat utomlands än till personer som studerat i Sverige. Under 2016 utfärdades 2446 läkarlegitimationer och cirka $50 \%$ av dessa var till personer som utbildats i EU eller EES.

${ }^{3}$ Läsåret 2016/17 var det 2489 personer som studerade till läkare utomlands med studiemedel från Centrala studiestödsnämnden. Majoriteten av dessa studerade i Polen.

${ }^{4}$ Projektet, Utlandsrekryterade läkares inskolning $i$ sjukvårdssvenska i Polen, är finansierat av Östersjöstiftelsen.

${ }^{5}$ Europarådets referensram (CEFR) beskriver språkkunskaper på sex nivåer: A1-C2. Gränsvärdena som anges i artikeln var aktuella 2015, då datainsamlingen gjordes. Därefter gäller C1-nivå (Socialstyrelsen 2018b).
} 
Analyserna som presenteras här är baserade på ett material som samlats in under en av svenskkurserna i Polen, där vi som forskare arrangerat läkarepatientsamtal i form av rollspel vid två tillfällen, i mitten och slutet av kursen. Vårt syfte är att ta reda på ifall läkarna utvecklat sin interaktionella kompetens, det vill säga förmåga att tolka och utföra språkhandlingar i socialt samspel, vilket vi gör genom att undersöka läkarnas sätt att ställa frågor och följa upp patienternas problembeskrivningar. Ett delsyfte är att undersöka hur deltagarnas allmänna språkfärdighet utvecklats.

Svenskkursen i Polen består mestadels av skriftspråksorienterad undervisning, utförd av polska lärare med utbildning i skandinavistik. Man följer i princip upplägget i Rivstart-serien (Levy Scherrer \& Lindemalm 2007, 2009), ett läroboksmaterial som ofta används i andraspråksundervisning i Sverige. Rollspelsövningar kan förekomma, men spontana dialoger är inte något frekvent inslag i undervisningen. Omkring femton procent av tiden ägnas åt medicinsk svenska. ${ }^{6}$

\section{Interaktionell kompetens}

Begreppet interaktionell kompetens kan definieras som förmågan att samordna handlingar i interaktion relaterat till situationella förväntningar (Hall \& Pekarek Doehler 2011). Interaktionell kompetens innefattar ett flertal förmågor och kunskaper som en samtalsdeltagare behöver för att framgångsrikt kunna delta i social interaktion, bland annat förmåga att känna igen kontextspecifika samtalsmönster, konstruera turer så att de är igenkännbara för andra samt reparera problem och upprätthålla gemensam förståelse i samtal (Hall \& Pekarek Doehler 2011). ${ }^{7}$

Begreppet bygger enligt Young (2011) på tidigare teorier om kompetens, men till skillnad från kommunikativ kompetens, som räknas som en egenskap hos en individ, är interaktionell kompetens något som samkonstrueras av deltagarna i interaktionella praktiker. Interaktionell kompetens är, enligt Young, "not what a person knows, it is what a person does together with others» (2011 s. 430). Begreppet har sina rötter inom två olika forskningsdiscipliner, lingvistisk antropologi och conversation analysis (CA), där det började användas un-

\footnotetext{
${ }^{6}$ Muntlig uppgift under en intervju med kursens föreståndare, 9 juni 2015.

${ }^{7}$ För att understryka mångfalden använder vissa forskare termen i pluralform, interactional competencies (Kasper 2006 s. 86).
} 
gefär samtidigt (Hall 2018). Den lingvistiskt antropologiska traditionen, där till exempel Young ingår, fokuserar mer på hur individuell kunskap varierar i olika praktiker, medan CA-traditionen fokuserar mer på de universella strukturer för interaktion som samtalsdeltagare orienterar sig mot, oberoende av situation. Dessa två perspektiv har senare kombinerats (se vidare Hall 2018). För vår del ansluter vi oss närmast till den lingvistiskt antropologiska traditionen.

Interaktionell kompetens har fått ökad betydelse inom forskningen om andraspråksutveckling (Hall 2018), vilket innebär ett ökat fokus på meningsskapande i interaktion och de resurser som andraspråkstalare använder sig av för att göra sig förstådda och samspela med andra. Förmågan till interaktion i olika situationer är både kontextoberoende och kontextkänslig; i det senare ingår både att fortlöpande anpassa sig till vad som händer i samtalet och andra faktorer som har med den pågående aktiviteten att göra (Pekarek Doehler \& Petitjean 2017).

Forskningen om andraspråksutveckling har traditionellt varit inriktad på strukturella och kognitiva faktorer (Håkansson \& Norrby 2010). Under senare år har socialt förankrad forskning om de interaktionella resurser som används av andraspråkstalare vuxit sig starkare (Hall \& Pekarek Doehler 2011) och utmanat den tidigare etablerade uppfattningen där språkfärdighet ses som en separat komponent (jfr Bachman \& Palmer 1996). I stället betraktas språkfärdighet som en integrerad del (Markee 2008, Hall \& Pekarek Doehler 2011, Young 2011), eller som Markee (2008 s. 406) uttrycker det: »[d]eveloping interactional competence in a second language includes but goes beyond learning language as a formal system».

För vuxna andraspråksinlärare är interaktionell kompetens både en resurs och ett objekt för lärande (Kasper 2006). Rollspelen efterliknar det institutionella anamnessamtalet och läkarna förmodas här kunna dra nytta av sina tidigare erfarenheter av att genomföra denna typ av samtal på sitt modersmål. Vårt upplägg ger oss möjlighet att undersöka deltagarnas utveckling genom att studera hur de tar sig an samma uppgift vid två tillfällen. En svårighet är dock att urskilja vad som är ett resultat av utveckling och vad som beror på kontextuella skillnader (Sahlström 2011, Waring 2018). CA-forskning har traditionellt inte haft utveckling i fokus, och frågor som rör sambandet mellan lärande och interaktion återstår att reda ut (Hall \& Pekarek Doehler 2011). Allt fler forskare inom CA har dock intresserat sig för lärande som ett interaktionellt fenomen (se t.ex. Melander \& Sahlström 2011, Sahlström 2011, Nguyen 2012, Markee \& Kunitz 2013). 
Enligt Nguyen (2012) innebär interaktionell kompetens inom ramen för en institutionell diskursiv praktik bland annat förmåga att hantera sekventiellt organiserade handlingar i relation till det övergripande syftet och att hantera topiker som en del av samtalets sekventiella organisation. Dessa förmågor är specifika för varje diskursiv praktik. I vår studie har vi valt att operationalisera interaktionell kompetens på så vis att den handling vi fokuserar på är läkarnas sätt att ställa frågor i relation till frågemönster som påvisats i tidigare studier av läkare-patientsamtal, såsom Lindholm (2003), Boyd \& Heritage (2005), Heritage \& Maynard (2005) och Heritage (2010). Analysfokus ligger på hur läkarna ställer följdfrågor och på andra sätt följer upp patienternas problembeskrivningar.

\section{Tidigare forskning}

Forskningen om flerspråkigas utveckling av interaktionell kompetens på ett andraspråk har länge varit eftersatt. Att det tidigare fanns relativt få sådana studier konstateras exempelvis av Hall \& Pekarek Doehler (2011). De studier som gjorts har ofta gällt undervisningssammanhang, till exempel Cekaites studie (2007) av ett barns utveckling av interaktionell kompetens under sitt första år i en svensk skola och Young \& Miller (2004), som i en longitudinell studie visar att oerfarna talare av ett språk bara använder en mindre uppsättning interaktionella resurser. På senare år har allt fler forskare ägnat sig åt studier av utvecklingen av interaktionell kompetens utanför undervisningssituationer. Ett exempel är en studie av hur en au pair i Schweiz under en period av nio månader ökar sin förmåga att utnyttja resurser för att framföra vardagliga berättelser på ett andraspråk (Berger \& Pekarek Doehler 2018). Den och ett flertal andra studier inom samma område har samlats i en nyutgiven antologi av Pekarek Doehler m.fl. (2018). I antologin diskuteras också tidigare longitudinella studier i relation till klassisk CA-forskning (Wagner m.fl. 2018).

Många undersökningar har gjorts av rollspel som metod för språktestning, till exempel för utländska läkare i länder som Australien och Nya Zeeland, där man liksom i Sverige tar in många utlandsutbildade läkare (McNamara 1997, Wette 2011, Pill \& Mcnamara 2016, Woodward-Kron \& Elder 2016). Av forskning om rollspel som språkutvecklingsmetod i andraspråksundervisning har framgått att rollspel producerar alla typer av samtalsaspekter, enligt Kasper 
(2000), som lyfter fram metodens potential att synliggöra kulturbundna drag $\mathrm{i}$ interaktion.

Rollspel som pedagogisk metod förekommer allmänt i medicinska utbildningar, och metodens användbarhet har undersökts i en rad studier internationellt (t.ex. Joyner \& Young 2006, Nestel \& Tierney 2007, Luttenberger m.fl. 2014). Ett nordiskt exempel är Thomassen (2005), som analyserat rollspel mellan medicinstudenter och verkliga patienter i läkarutbildningar i Norge. Studien visar att det finns tvetydigheter på olika nivåer för deltagarna att hantera. En sådan är osäkerhet om vad det är för verksamhetstyp man deltar i, det vill säga om rollspelet ska uppfattas som en autentisk situation eller som en övningssituation. Linell \& Persson Thunqvist konstaterar också att rollspel innefattar »complexities and hybridities on several planes» (2003 s. 409), i en studie av arbetssökande. Studien pekar på problem med bibehållet fokus på rollspelandet och visar att deltagarnas uppfattning om verksamhetens inramning kan variera under samtalets gång. Rollspel kan således karakteriseras som en hybrid verksamhetstyp.

Med vår studie vill vi bidra med kunskap om utveckling av interaktionell kompetens hos vuxna språkinlärare, relaterat till yrkesanknutet samtalande i en ny institutionell språkmiljö. För att åstadkomma en longitudinell design använder vi oss av rollspel och hoppas därmed i någon mån även kunna bidra med didaktisk kunskap om rollspel som språkutvecklingsmetod.

\section{Material och metoder}

Den totala datainsamlingen i Polen gjordes vid tre tillfällen under sammanlagt tio dagar och genomfördes av Kahlin och Tykesson. Deltagare från två kurser under olika perioder ingick i studien. Under mötet med deltagare på den första kursen (16 personer) genomfördes intervjuer och observationer av undervisningen. Under mötena med deltagare på den andra kursen (14 personer) var vi huvudsakligen inriktade på att elicitera ett samtalsmaterial i form av rollspel, som vi designat för forskningsbruk. Rollspelen arrangerades av oss. De ägde rum under lektionstid, men ingick inte i den ordinarie undervisningen. Det hela presenterades för deltagarna som ett led i vår forskning och inte som ett undervisningspass. Deltagandet var frivilligt, men samtliga 14 kursdeltagare valde att vara med. 
Rollspelen genomfördes och spelades in vid två tidpunkter med samma deltagare, fördelade i halvgrupp. Rollspel 1 (RS1) gjordes under den 6:e kursveckan och rollspel 2 (RS2) under den 12:e kursveckan (se tabell 1).

Tabell 1. Rollspel: läkare-patientsamtal, audioinspelade.

\begin{tabular}{lllll}
\hline & Plats & Tid & Antal deltagare & Inspelningslängd \\
\hline RS1 & Polen & 6:e kursveckan & 14 (2 grupper) & 2 tim 45 min \\
RS2 & Polen & 12:e kursveckan & 14 (2 grupper $)$ & 2 tim 19 min \\
\hline
\end{tabular}

Vid tidpunkten för RS2 hade deltagarna fått undervisning i medicinsk svenska, vilket inte ingått före RS1, däribland en lektion i anamnessamtal. Som igångsättare för rollspelen visade vi sammanlagt fyra filmer med läkare-patientsamtal, två filmer före respektive tillfälle. Det är filmer som används i undervisningen av medicinstudenter i Sverige. I samband med filmvisningarna gavs utrymme för kommentarer och frågor. Vissa av kursens lärare deltog vid filmvisningarna, men under rollspelen var inga lärare närvarande.

En av projektdeltagarna, Mihaela Romanitan, som är läkare och neurologspecialist, har bidragit med att skapa realistiska sjukdomsfall att använda $i$ rollspelen. Allt som allt hade vi förberett åtta fall. Varje läkare i respektive halvgrupp fick ett eget sjukdomsfall, samma fall och samma patient båda gångerna. Vi har alltså strävat efter att konstanthålla så många faktorer som möjligt, för att underlätta möjligheten att göra jämförelser. Alternativet att utsätta respektive läkare för en patient med en ny diagnos valde vi bort, eftersom vi bedömde att deltagarna ändå rätt snart skulle kunna lista ut vilken av våra åtta diagnoser som var aktuell, med tanke på att de suttit med som åhörare till varandras rollspel. Läkarna var inte informerade i förväg om att samma fall skulle återkomma vid det andra tillfället, vilket är viktigt att nämna.

I grupperna ingick yrkeserfarna läkare med specialistkunskaper inom olika discipliner och vissa, men inte alla, fick ett fall som var anpassat till deras specialisering. ${ }^{8}$ Kahlin och Tykesson turades om att agera patienter. För deltagarna markerade vi att vi ville ha en tydlig rollfördelning som innebar att en av oss enbart agerade patient, medan den andra, »bisittaren», var tillgänglig för stöttning, ifall läkaren själv uttryckte en önskan om språkhjälp. På så sätt ville vi sätta en tydlig ram för rollspelet och så långt som möjligt undvika att bryta il-

\footnotetext{
${ }^{8}$ Av forskningsetiska skäl går vi inte in på vilka medicinska och andra specialområden som fanns representerade.
} 
lusionen att läkaren befann sig inför en verklig patient. Bisittarens roll var främst att kunna gripa in ifall samtalet skulle stoppas upp alldeles, exempelvis av ordsökning (jfr Linell \& Persson Thunqvist 2003). Syftet var att försöka minimera hybriditetsproblemet.

Varje rollspel pågick i cirka sex minuter, med variationer både uppåt och nedåt $\mathrm{i}$ tid (det kortaste varade 3:44 minuter och det längsta 8:40 minuter). Vid inspelningarna användes endast audioinspelning. På grund av vårt beslut att inte filma rollspelen har vi inte tillgång till deltagarnas icke-verbala handlingar som underlag för våra analyser. Det är en svaghet med vår studie, men $i$ valet mellan att rigga upp en filmkamera eller använda ett mer diskret inspelningssätt bestämde vi oss för det senare alternativet av det skälet att vi inte ville riskera att göra deltagarna onödigt spända i dessa tidiga faser av språkinlärning.

Samtliga 28 rollspel har transkriberats. I analyserna av rollspelen använder vi metodologiska verktyg från CA, som utvecklats för att demonstrera empiriskt hur parter i naturligt förekommande samtal interagerar på tur för tur-basis (se t.ex. Heritage 1984, Sacks 1992). Trots att de samtal vi analyserar är arrangerade, utgår vi från principen om deltagarperspektiv, som är bärande inom CA (Schegloff 1996). Principen innebär att den som analyserar söker få grepp om hur deltagarna själva tolkar varandras samtalsbidrag. Det är tänkbart att vi i rollen som patienter anpassar våra yttranden efter våra antaganden om läkarnas språkliga nivå, vilket gör det extra viktigt att analysera interaktionen utifrån de tolkningar som görs i situationen, till exempel av läkarnas intonation. I rollen som patienter är vi hänvisade till de resurser som finns tillgängliga under det pågående samtalet, det vill säga samma resurser som används i naturliga samtal med andraspråkstalare för att avgöra om tillräcklig intersubjektivitet verkar vara uppnådd.

Analysdelen som följer inleds med en kort, kvantitativ analys av läkarnas språkproduktion vid vart och ett av rollspelstillfällena. Den är gjord i syfte att ge en översiktlig bild av läkarnas språkfärdighet, som i denna analysdel undersöks som en separat komponent. Efter det korta, inledande avsnittet ligger tonvikten på kvalitativ analys. Då analyseras för det första hur två av läkarna följer upp patienternas yttranden genom olika typer av följdfrågor i RS1 och RS2, för det andra läkarnas återbruk av centrala ord i patienternas yttranden och för det tredje en annan typ av verbalt återbruk, nämligen läkarnas användning av turinledande repetitioner som resurs i frågesekvenser. 


\section{Läkarnas ökade språkproduktion}

Innan vi går in på de kvalitativa analyserna av läkarnas utveckling av interaktionell kompetens vill vi som en bakgrund beskriva övergripande tendenser i hur läkarnas språkliga produktion på ord- och turnivå utvecklats mellan de två rollspelstillfällena. Denna första, kvantitativa analys gäller enbart läkarnas samtalsbidrag. Det innebär att vi temporärt lämnar vårt övergripande, dialogiska perspektiv för ett mer monologiskt perspektiv. Den kvantitativa analysen baseras på transkriptioner av läkarnas turer i samtliga rollspel. Eventuellt förekommande sekvenser av frågor till bisittaren har tagits bort.

Resultaten gällande samtalslängd, antal ord och antal turer i samtalet varierar avsevärt mellan individerna. Den stora variationen mellan individerna kan delvis förklaras av att de har fått olika fall att ta sig an, och vissa är komplicerade och kräver mer interaktionellt arbete än andra.

Talhastighet är den komponent i språkproduktionen som visar på störst förändring. Hos samtliga läkare ökar antalet ord per minut i RS2 (läkarens ordproduktion är då uträknad i relation till den totala tid som samtalet pågår). För vissa är ökningen inte stor, för andra väsentligt större. Den genomsnittliga ökningen är 11 ord per minut. En annan komponent som pekar på att det skett en förändring är det totala antalet ord som läkarna producerar. I RS1 varierar ordmängden från 45 till 271 ord och i RS2 från 157 till 359 ord (ord som upprepas har då räknats varje gång det förekommer). Alla utom en läkare använder fler ord totalt vid det andra tillfället, och intressant nog gäller detta oavsett om den individuella läkarens rollspel då pågick längre eller kortare tid än vid det första tillfället.

Värt att notera är att den största ökningen av antalet ord finns hos de tre läkare som använder lägst antal ord i RS1. Av dessa är det två som använder cirka dubbelt så många ord i RS2 och en som använder fyra gånger så många ord i RS2. Så gott som samtliga (13 av 14 läkare) har också längre turer i genomsnitt i RS2. ${ }^{9}$ Det antal turer respektive läkare använder varierar från 11 till 50 turer i RS1 och från 18 till 42 turer i RS2. Även förekomsten av tvekljud (äh, öh, eh etc.) visar på individuell variation, men hos flertalet (9 av 14 läkare) minskar användningen av tvekljud i RS2.

Kvantitativa jämförelser som dessa kan vara missvisande, eftersom situationella faktorer varierar. Att göra sådana jämförelser innebär därför ett avsteg från samtalsanalytisk teori, som utgår från att ett samtal alltid är situerat

\footnotetext{
${ }^{9}$ Med tur avses en persons hela yttrande, som kan bestå av en eller flera turkonstruktionsenheter. En tur avgränsas i praktiken av talarbyte (Lindström 2008). Uppbackningar räknas inte som en tur.
} 
och specifikt (se t.ex. Sacks m.fl. 1974), ett argument som för övrigt kan riktas även mot longitudinella kvalitativa studier. Mångordighet behöver ju heller inte alltid vara ett uttryck för progression. En annan metodkritisk aspekt är att den ökade förmågan att genomföra patientsamtal i RS2 delvis också kan förklaras av att läkarna har fördel av att redan ha genomfört ett samtal om ifrågavarande åkomma, eftersom de fått samma fall två gånger. Dock hade det gått fem veckor mellan tillfällena, så all förändring kan inte förklaras av att läkarna kan ha reflekterat över sin första prestation och senare förmått anpassa sina frågeturer på grund av sin förkunskap om den aktuella diagnosen. Läkarna var heller inte informerade i förväg om att de skulle få samma fall andra gången. Situationell anpassning kan dessutom inte överföras från ett samtal till ett annat, beroende på det nyss nämnda förhållandet att två samtal aldrig är identiska.

Tendensen att kursdeltagarna förmår tala snabbare och med större flyt vid det andra rollspelstillfället är trots allt tydlig, och det ser vi som belägg för att deltagarna utvecklat sin språkfärdighet efter ytterligare fem veckors studier, vilket också är förväntat, med tanke på det intensiva undervisningstempot och läkarnas motivation och studievana.

\section{Analys av läkarnas frågemönster}

I denna första del av den kvalitativa analysen jämförs två av läkarna (läkare $\mathrm{E}$ och $\mathrm{G}$ ) och hur de följer upp patientens (P:s) initiala beskrivning av sina symtom genom olika typer av följdfrågor i RS1 respektive RS2. Dessa båda läkare har valts ut dels därför att de var och en på sitt sätt lyckas genomföra uppgiften förhållandevis väl redan i RS1, dels för att det hos båda finns relativt många uttryck för progression från det första till det andra rollspelstillfället. Det vi undersöker är hur läkarna samordnar sina interaktionella resurser under en första, inledande anamnesdel i samtalet. Liksom i andra typer av institutionella samtal ligger ansvaret för att interaktionen genomförs i enlighet med samtalets syfte på den professionella parten (Nguyen 2012). I likhet med studier av autentiska läkarsamtal urskiljer sig i rollspelen ett mönster i denna informationssökande del. Den inleds vanligen av en öppen, allmänt ställd fråga, vilken i regel följs upp av ett antal följdfrågor, för att framkalla en fylligare och mer precis beskrivning (Heritage 2010). Genom frågorna sätter läkarna agendan för olika delmoment av samtalet (Boyd \& Heritage 2005) och driver samtalet framåt ge- 
nom frågor i samklang med samtalets övergripande syfte. Med följdfråga avses här en fråga som innehållsligt knyter an till en föregående fråga, till exempel genom en begäran om precisering.

I utdrag (1) från RS1 använder läkaren (L) den inledande frågan »Hur kan jag hjälpa dig?». ${ }^{10}$ Öppna frågor inledda av ett frågeord används i regel för att efterfråga information av allmänt slag och uppmuntrar till responser som består av flera innehållselement (Lindholm 2003), precis som i responsen i (1), rad 23 , där P allmänt beskriver sina problem med huvudvärk. Uppmaningen på rad 11-12 uppmuntrar på ett liknande sätt till en utvecklad beskrivning. L ställer flera följdfrågor som introducerar nya deltopiker: på rad 5-6 och rad 8 efterfrågas information om var värken sitter. (Läkarnas frågor är fetmarkerade $\mathrm{i}$ transkriptionsutdragen 1-4.)

(1) RS1, läkare E (migrän)

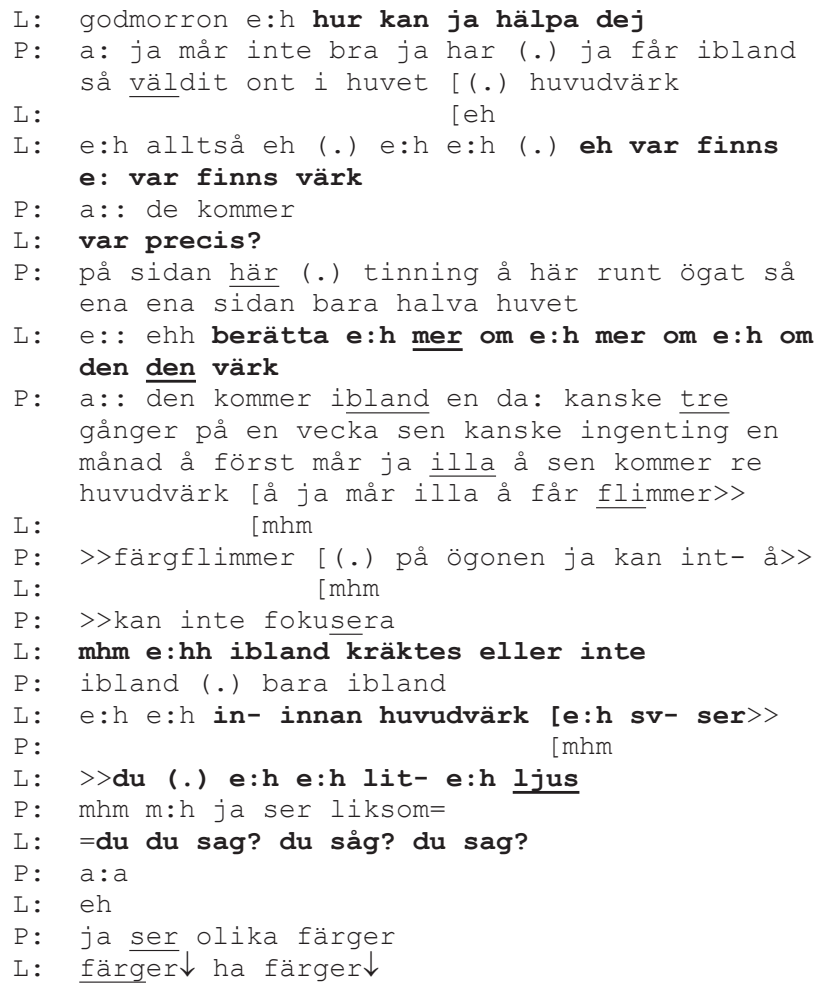

${ }^{10}$ Frågan förekommer i de filmer som visades före rollspelen och används i 22 av rollspelen, formulerad på samma eller liknande sätt. 
32 P: som rör sej (.) flimmer

33 L: flimmer flimmer $\downarrow$ okej (.) e:h hur länge har

34 du haft

Denna inledande frågesekvens i (1) hålls samman av innehållsordet värk som L använder i två av frågorna ( $\operatorname{rad} 6,11-12$ och 23) och som återknyter till P:s inledande symtombeskrivning. På rad 23 och 25 ställer L en ledande fråga som är typisk för diagnostiserande frågor. Frågan är ja-optimerad, det vill säga innebär en grammatisk preferens för ett instämmande svar (Heritage 2010) och innehåller antaganden om symtom som skulle kunna höra samman med det problem som P beskriver. Således uppvisar detta samtal i RS1 redan drag som är typiska för ett läkare-patientsamtal. L har dock vissa svårigheter med att formulera sin fråga så att $\mathrm{P}$ beskriver de aktuella symtomen tillräckligt utförligt. Uppmaningen e:: ehh berätta e:h mer om e:h mer om e:h om den den värk på rad 11-12 ställs med flera tvekljud och omstarter. Dialogen är överlag utdragen, särskilt från rad 15 och framåt när $\mathrm{P}$ beskriver sina symtom innan värken kommer, bland annat genom att L upprepar vissa centrala ord (yttrandet analyseras vidare i utdrag 8). Samtalet präglas av tvekljud och andra typer av uppskjutande drag från L, vilket tyder på att L behöver tid för att hitta ord, till exempel L:s självinitierade självreparation $d u$ du sag? du såg? du sag? ( $\operatorname{rad} 27)$. Denna självreparation, liksom några repetitioner som flimmer flimmer $(\operatorname{rad} 33)$, kan också vara ett tecken på att L (här) ser rollspelet som en övningssituation, och kan alltså vara ett uttryck för rollspelets hybriditet. En svårighet med att bedöma detta är att självinitierade självreparationer generellt är vanligt förekommande i andraspråkssamtal (Markee 2000 s. 31).

I RS2 ställer samma läkare mer fokuserade följdfrågor och beskrivningen av symtomen görs på ett mer effektivt sätt.

(2) RS2, läkare E (migrän)






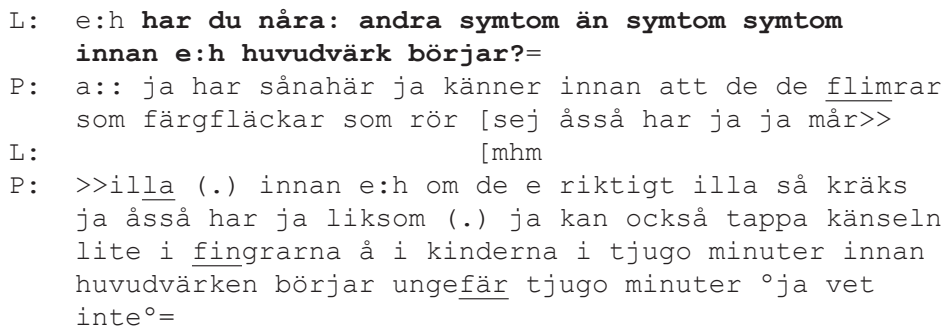

I (2) inleds samtalet med samma öppna fråga som i (1) och responsen består av en allmän beskrivning med flera innehållselement. Den skiljer sig från (1) genom att $P$ själv anger en diagnos. Därefter ställer L en fokuserad följdfråga om när huvudvärken började ( $\operatorname{rad} 5)$. Genom den specifika frågan demonstrerar L tydligare än i RS1 att han förstått att P lider av återkommande problem och inte söker hjälp akut. Frågan resulterar i en utvecklad beskrivning av P:s besvär över tid. Därefter ställer L en preciserande följdfråga som presupponerar att $P$ lider av ensidig huvudvärk. Frågan besvaras snabbt och följs upp av en fokuserad kontrollfråga: alltid $\uparrow(\operatorname{rad} 13)$. När L liksom i RS1 frågar om vilka symtom som föregår huvudvärken görs detta i form av en öppen fråga, som denna gång snävar in det delområde L vill ha information om ( $\operatorname{rad} 15-16)$. Det leder till att $\mathrm{P}$ beskriver de symtom som föregår huvudvärken på ett sammanhängande och mer precist sätt än i RS1.

Rollspelen kännetecknas i likhet med verkliga läkare-patientsamtal av ett samspel mellan deltagarna. I både (1) och (2) leder samspelet mellan L och $\mathrm{P}$ till en sammanhängande symtombeskrivning från P. L uppvisar interaktionell kompetens även i RS1 genom att redan då förmå ställa följdfrågor som bidrar till att problemen beskrivs tämligen detaljerat. Dock ökar mängden information från P i RS2. L:s ökade interaktionella kompetens visar sig bland annat genom att följdfrågorna i RS2 knyter an till tidigare yttranden på ett tydligare sätt. Att de dessutom framförs med färre tvekljud och omstarter, vilket troligen är ett resultat av ökad språkfärdighet, bidrar till och ingår i en ökad interaktionell kompetens (jfr Markee 2008).

Den andra läkaren, G, ställer i (3), RS1, ungefär samma öppningsfråga som E, och i sin respons beskriver P sina symtom med flera innehållselement. Det framgår att P:s arm har känts konstig sedan $i$ morse ( $\operatorname{rad} 2)$, alldeles som domnad ( $\operatorname{rad} 3)$. Beskrivningen följs endast upp av en uppbackning ( $\operatorname{rad} 4)$ från L, som därpå ställer en fråga som förekommer i nästan alla rollspelen: $e$ : hur gammal är du? . Frågan och svaret om P:s ålder bildar en inskottssekvens ( $\operatorname{rad} 6-8)$ som bryter av flödet i utredningen av P:s besvär. L avviker därmed från mönst- 
ret som innebär att symtomen i P:s första allmänna respons följs upp med direkt relaterade följdfrågor.

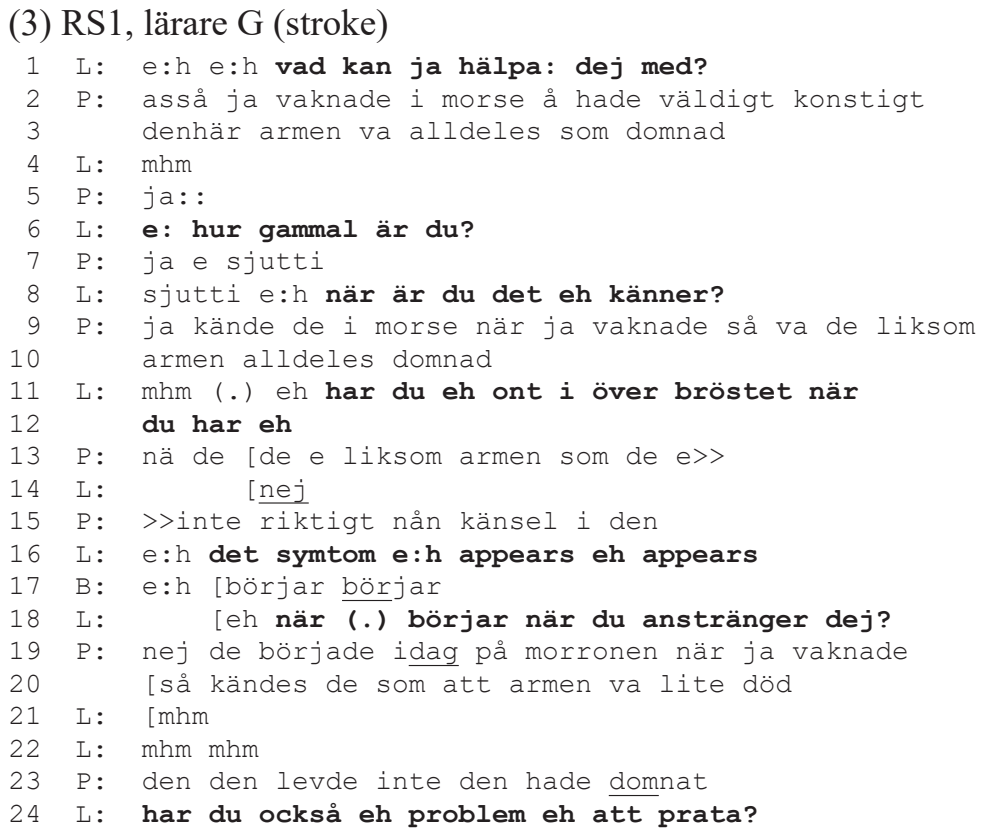

Först på rad 8 ställs en följdfråga (e:h när är du det eh känner?) som knyter an till patientens inledande problembeskrivning. P svarar: ja kände de i morse när ja vaknade och upprepar sedan informationen om att armen är domnad, vilket tyder på att $\mathrm{P}$ gör tolkningen att $\mathrm{L}$ inte uppfattat all information om problemet med armen. L fortsätter med en fokuserad fråga: e:h det symtom e:h appears eh appears (rad 16) men hittar inte rätt ord utan söker och får viss hjälp av bisittaren ( $\operatorname{rad} 17)$. L börjar om med frågan eh när (.) börjar när du anstränger dej? ( $\operatorname{rad} 18)$, varpå P beskriver känslan i armen mer utvecklat, i flera svarsturer (från rad 19).

Även om utfrågningen löper lite osäkert och med många tvekljud, innehåller (3) för aktiviteten typiska följdfrågor. L ställer tre ledande följdfrågor ( $\operatorname{rad} 11$ $12,16,18$ och 24) som presupponerar symtom utifrån vad som troligen är L:s hypotes om P:s diagnos (stroke). Följdfrågorna är utformade som fokuserade frågeordsfrågor. Den typen av frågor används typiskt i läkare-patientsamtal för att begära specifik information eller en precisering, tills läkaren har fått tillräckligt med information (Lindholm 2003 s. 58 f.). 
I (4), med samma läkare i RS2, följs P:s första allmänna symtombeskrivning upp direkt av en öppen följdfråga: vad menar du? ( $\operatorname{rad} 3)$.

(4) RS2, läkare G (stroke)

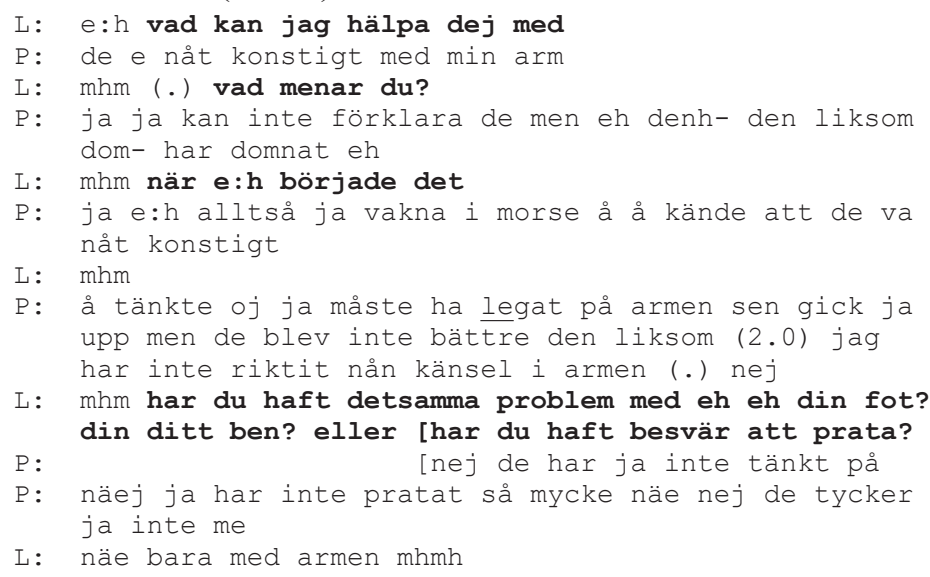

Följdfrågan vad menar du? ( rad 3) leder till att $\mathrm{P}$ fortsätter att beskriva sin känsla i armen. Därefter ställs en fokuserad följdfråga om när symtomen började ( $\operatorname{rad} 6)$. Det leder till en utvidgad tur där $\mathrm{P}$ först svarar på frågan och sedan utvecklar sin beskrivning. Därefter följer en flerledad fråga, tre ja/nej-frågor med presupponerade relaterade symtom ( $\operatorname{rad} 13-14)$. P besvarar dessa $\mathrm{i}$ två olika turkonstruktionsenheter, varpå L bekräftar sin förståelse av P:s huvudsakliga problem (näe bara med armen, rad 18). Den kommentaren återkopplar till P:s beskrivning och fungerar som en bekräftande avslutning på topiken. Genom den, liksom genom den flerledade frågan på rad 13-14 (har du haft detsamma problem med eh eh din fot? osv.), demonstrerar L även sin förståelse av P:s yttranden.

Läkare $\mathrm{G}$ följer det typiska samtalsmönstret för läkare-patientsamtal redan i RS1, men i RS2 leder läkare G:s sätt att ställa frågor till att P:s symtombeskrivning blir mer koherent och effektiv jämfört med RS1. Genom följdfrågor som knyter an innehållsligt möjliggörs en fylligare beskrivning kring huvudsymtomen innan obligatoriska delar (som ålder) betas av. Den flerledade frågan på rad 13-14 i (4) bidrar till att några av L:s antaganden om symtom enkelt kan dementeras. Läkare G uppvisar också en tydligare förståelse av vad P har sagt i RS2. Läkare E följer en liknande utveckling.

Av analyserna av dessa två läkare vill vi dra slutsatsen att det skett en utveckling av den interaktionella kompetensen. Liksom när det gäller vår slutsats i fö- 
regående avsnitt, att deltagarna utvecklat sin allmänna språkfärdighet, kan den invändningen göras att den ökade förmågan att genomföra patientsamtalet också kan förklaras av att läkarna fick samma fall att ta sig an i RS2. Något som talar emot den invändningen är att förmågan till situationell anpassning blir än viktigare när det gäller följdfrågor, eftersom sådana i hög grad måste anpassas till föregående yttrande.

\section{Verbalt återbruk}

I detta avsnitt analyseras ett sätt att knyta an till något som samtalspartnern sagt genom det Anward $(2000,2004)$ kallar för språklig återanvändning (se även t.ex. Tannen 1989, Landqvist 2010). Enligt Anwards återanvändningsteori lagras yttranden som fälls i ett samtal i minnet och används som byggstenar i nya yttranden. I rollspelen förekommer verbalt återbruk inbakat i läkarnas följdfrågor och kommentarer till patienternas beskrivningar av olika symtom. Det finns exempel i RS1, som i fallet med värk i (1), men annars förekommer det bara undantagsvis i RS1.

Ett exempel på verbalt återbruk i RS2 visas i (5), där P i sin beskrivning av ett symtom använder ordet onormalt ( $\operatorname{rad} 2)$, vilket plockas upp i L:s värderande kommentar de e inte normalt ( $\operatorname{rad} 5)$. Sådan användning av delar av en gammal tur kallar Anward (2004 s. 40) för »recycling with différance». (De återanvända orden är fetmarkerade i båda talarnas turer i transkriptionsutdragen 5-7 nedan.)

(5) RS2, läkare L (tarmproblem)

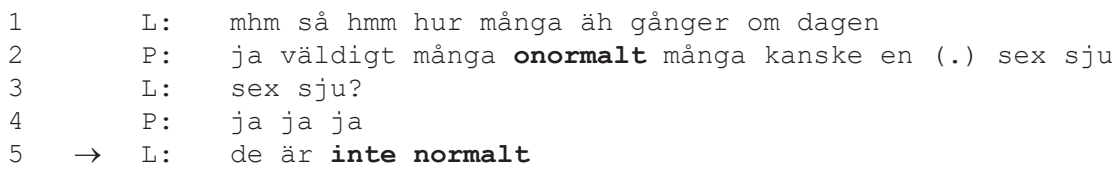

Samma fenomen finns i (6), där L i sin följdfråga äh när började ditt problem me äh äh sov? ( $\mathrm{rad} 4)$ knyter an till att $\mathrm{P}$ använt verbet sova i sin symtombeskrivning $(\operatorname{rad} 1)$.

(6) RS2, läkare J (sömnproblem)

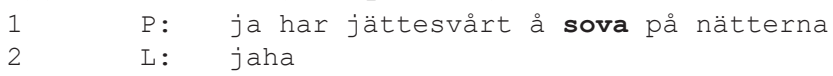




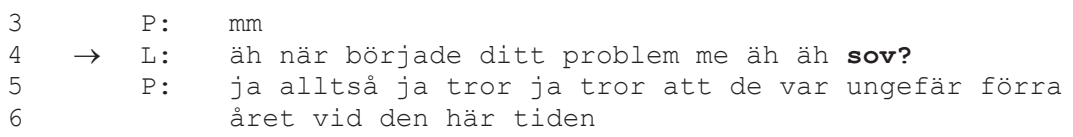

Frågan när började du att känna dej stressad? (rad 3) i (7) är ett annat exempel på en mer specifik följdfråga i RS2. För att få besked om hur länge P haft sina symtom, plockar L upp ordet stressad, som är ett av de olika symtom som $\mathrm{P}$ nämner i den föregående turen ( $\operatorname{rad} 1-2)$.

(7) RS2, läkare B (panikångest)

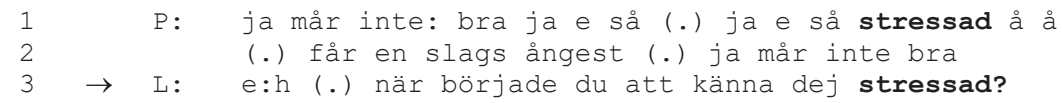

Att läkarna bygger vidare på den problembeskrivning som framkommit genom att upprepa ord eller delar av ord som P använt förekommer alltså i större utsträckning i RS2. Det visar på en skillnad jämfört med mönstret i RS1, som i stället består i att läkarna ställer mer allmänna följdfrågor som kan matcha varierande problembeskrivningar, såsom »Har du några andra symtom?» och »Hur länge har du haft det så?». ${ }^{11}$ Att anknyta mer specifikt till något symtom som patienten nämnt kan ha en förtroendeskapande effekt. Läkarnas sätt att följa upp patientens yttranden genom verbalt återbruk i RS2 visar på en ökad förmåga att demonstrera sin förståelse, vilket vi tolkar som en utveckling på gruppnivå av den interaktionella kompetensen.

\section{Repetition som resurs i frågesekvenser}

I denna avslutande del av analysen undersöks en annan typ av verbalt återbruk än i det föregående avsnittet, nämligen läkarnas bruk av turinledande repetitioner. Det är ett drag som förekommer så pass frekvent i läkarnas turer att vi ser det som ett mönster. Med repetition menas här identisk upprepning av ett eller flera ord i samtalspartnerns föregående tur. Baserat på en kartläggning av dessa lingvistiska element undersöker vi i det följande vilka sociala handlingar läkarna utför genom att upprepa något av det patienten just yttrat. Repetition är en mångfunktionell resurs som kan användas för att underlätta uppgiften att producera tal och för att göra samtalet mer koherent och tillgängligt, men också

${ }^{11}$ Den senare frågan förekommer i en av filmerna som visades före RS1. 
i strategier för att påverka lyssnaren, hävdar Norrick (1987), i en artikel där han ger en översikt av repetitioners funktion i samtal.

I vardagliga samtal förekommer repetitioner regelbundet i turinledningar (Schegloff 1987). Vår kartläggning av samtliga repetitioner visar att så är fallet också i läkarnas yttranden i rollspelen, men dessutom visar sig det dominerande mönstret vara att repetitionen i rollspelen ensam utgör en tur. Repetitioner förekommer i 20 av 28 rollspel och hos alla utom två av läkarna. Att repetitioner är potentiellt mångfunktionella gör avgränsningen mellan olika kategorier något diffus, »fuzzy», enligt Norrick (1987 s. 247), men vi har trots detta försökt oss på att kategorisera de förekomster vi kartlagt (se tabell 2). Det rör sig om totalt 45 förekomster, varav 28 i RS1 och 17 i RS2.

Tabell 2. Samtliga repetitioner, indelade $\mathrm{i}$ tre funktionskategorier. $\mathrm{F}=$ antal förekomster; $\mathrm{R}$ = antal rollspel där det finns förekomster. Rollspel per tillfälle: 14.

\begin{tabular}{lcccccccc}
\hline & 1. Ekorepetition & \multicolumn{2}{l}{$\begin{array}{l}\text { 2. Repetition } \\
\text { som bekräftelse }\end{array}$} & \multicolumn{2}{l}{$\begin{array}{l}\text { 3. Repetition } \\
\text { som begäran om } \\
\text { förtydligande }\end{array}$} & \multicolumn{2}{c}{ Totalt } \\
& F & R & F & R & F & R & F & $\mathrm{R}^{*}$ \\
\hline Rollspel 1 & 6 & 4 & 2 & 2 & 20 & 6 & $\mathbf{2 8}$ & $\mathbf{1 0}$ \\
Rollspel 2 & - & - & 10 & 5 & 7 & 5 & $\mathbf{1 7}$ & $\mathbf{1 0}$ \\
Totalt & $\mathbf{6}$ & & $\mathbf{1 2}$ & & $\mathbf{2 7}$ & & $\mathbf{4 5}$ & \\
\hline
\end{tabular}

* Respektive summa avser förekomst i antal olika rollspel, vilket inte kan utläsas av tabellen.

Tre huvudfunktioner har utkristalliserats i vår analys. Tolkningen av vilken huvudfunktion en repetition har är baserad på den reaktion som repetitionen leder till hos P. Kategori 1, ekorepetition, innefattar repetitioner som inte leder till någon hörbar respons hos samtalspartnern. Som framgår av tabell 2 finns det relativt få förekomster i den kategorin och enbart i RS1. I kategori 2, repetition som bekräftelse, finns de flesta förekomsterna däremot i RS2. Kategori 3 innefattar repetition som begäran om förtydligande. Andelen förekomster i denna kategori är störst i RS1. Det är också den största kategorin. (De repeterade orden är fetmarkerade i båda talarnas turer i transkriptionsutdragen 8-20 nedan.) 


\section{Ekorepetition (kategori 1)}

Norrick skiljer mellan repetitioner som utför vissa operationer, » significant repeats», och sådana som inte kräver någon särskild uppmärksamhet, »random repetition» (1987 s. 247). Repetitionerna i kategori 1, ekorepetition, påminner delvis om den senare, dock ser vi dem inte som slumpartade. Till kategorin ekorepetition hänför vi repetitioner som inte leder till någon hörbar reaktion hos samtalspartnern, utan att de för den skull avslutar ett lokalt projekt. Ett exempel är (8), där läkaren E i sina båda turer använder dubblerade repetitioner. ${ }^{12}$ Sådan egenupprepning av repetitioner förekommer inte i repetitioner inom de andra kategorierna.

(8) RS1, läkare E (migrän)

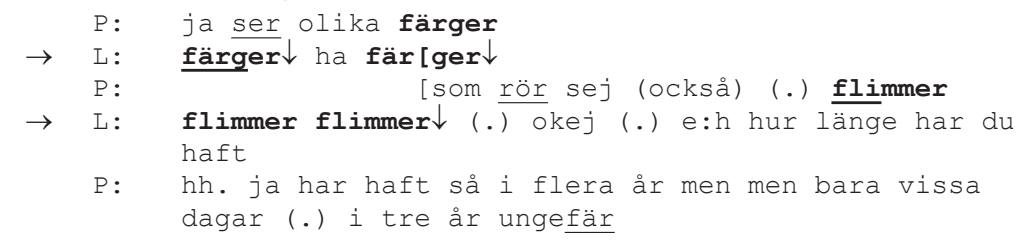

Den första av egenupprepningen i (8) (färger $\downarrow$ ha färger $\downarrow$ ) blir delvis överlappad av P:s nästa tur (rad 3). Efter den påföljande egenupprepningen, flimmer flimmer $\downarrow$ (.) okej ( $\operatorname{rad} 4)$, finns en möjlig turbytesplats, men L ställer en ny fråga och behåller därmed turen. Att ingen av repetitionerna i (8) föranleder någon hörbar respons från $\mathrm{P}$ tyder på att dessa repetitioner är samtalsdrag som inte kräver samtalspartnerns uppmärksamhet. Eventuellt uttalar L i (8) de repeterade orden i första hand för att bekräfta dem inför sig själv, ett förfaringssätt som bara förekommer i RS1. En möjlig tolkning är att L processar flimmer flimmer såväl som färger ha färger, på liknande sätt som samma läkare gör i exemplet du du sag? du såg? du sag? i (1), rad 27. Att inramningen av den pågående verksamheten därigenom växlar om från läkare-patientsamtal till övningstillfälle kan i så fall ses som ett uttryck för rollspelets hybriditet.

Ett exempel av delvis annorlunda karaktär är (9), där P inte fäster något avseende vid L:s repetition på kvällen $\downarrow(\operatorname{rad} 5)$, ett tidsuttryck som P själv för övrigt upprepat internt i den föregående turen ( rad 3-4). Här kan den uteblivna reaktionen eventuellt bero på att $\mathrm{P}$ inte uppfattar L:s repetition, ef-

${ }^{12}$ E är en av de två läkare som analyseras i avsnittet »Analys av läkarnas frågemönster», utdrag (1) och (2). 
tersom L:s repetition överlappar P:s tur på rad 4. P:s tur fortsätter också på $\operatorname{rad} 6$.

(9) RS1, läkare C (sömnproblem)

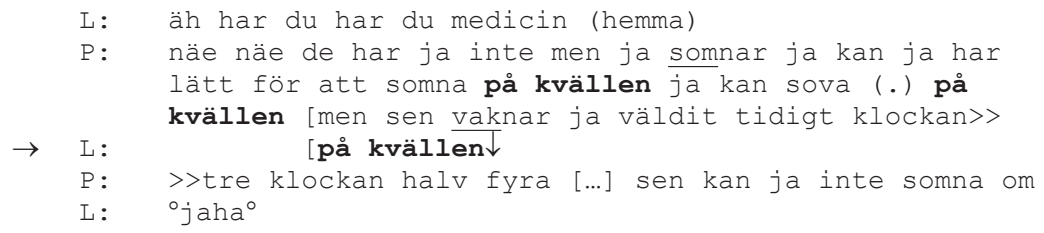

Repetitioner i kategorin ekorepetitioner förekommer i fyra av rollspelen i RS1, men förekomsterna är relativt få, totalt sex stycken. Ingen av läkarna använder ekorepetitioner i RS2. Att läkarna i RS2 låter bli att uttrycka sig på ett sätt som kan uppfattas som att de tänker högt och processar ett ord inför patienten ser vi som tecken på ökad interaktionell kompetens hos läkarna på gruppnivå. En alternativ tolkning är att deltagarna har ett ökat fokus på rollspelet som faktisk konsultation, snarare än en övningssituation.

\section{Repetition som bekräftelse (kategori 2)}

I frågesekvenser generellt kan repetitioner ha funktion som en signal om att svaret är noterat, enligt modellen fråga - svar - bekräftelse på svaret. Sådana kvittenser är vanliga när information ska föras in i ett formulär av något slag och används ofta för att avsluta en frågesekvens (Houtkoop-Steenstra 2000). Repetitioner som bekräftelse (kategori 2) har denna funktion. De avslutar ett lokalt projekt eller ingår i en turkonstruktionsenhet som avslutar ett sådant. I (10) kan även noteras att läkarnas användning av repetitioner som kvittenser på P:s svar ger läkarna en aning extra tid att planera nästa fråga i informationsinhämtandet.

(10) RS2 läkare M (panikångest)

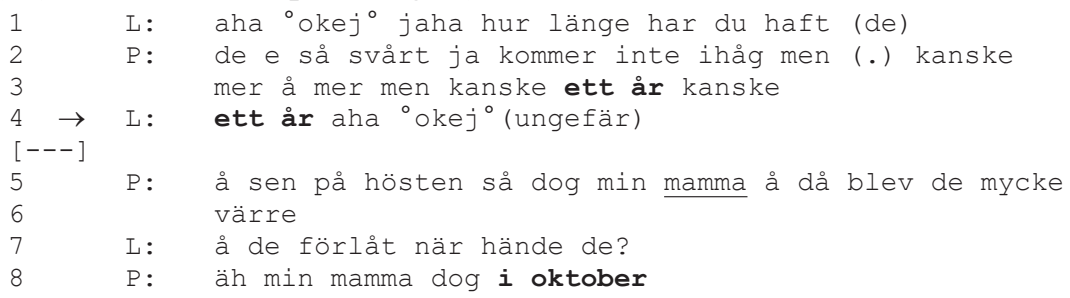




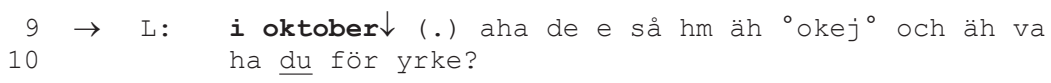

L i (10) vinner extra betänketid också genom att repetitionerna ett år respektive i oktober följs av småord som också fungerar bekräftande: aha okej ( $\operatorname{rad} 4)$ och aha de e så, följt av tvekljuden $h m$ äh samt okej ( $\operatorname{rad} 9)$. I samma tur som repetitionen $i$ oktober $\downarrow$, i en ny turkonstruktionsenhet ( $\operatorname{rad} 9-10)$, ställer L en fråga: och äh va har du för yrke?. I (11) uttrycker sig L på ett liknande sätt i sina turer i de återgivna sekvenserna: tjutre $\downarrow$ öhm har du tagit ( $\operatorname{rad} 3-5)$, det vill säga kvittens plus tvekljud plus ny (avbruten) fråga, respektive datakunskap $\downarrow$ jaha det svårt (rad 8-9), det vill säga kvittens plus värdering av svaret, följt av en ny fråga.

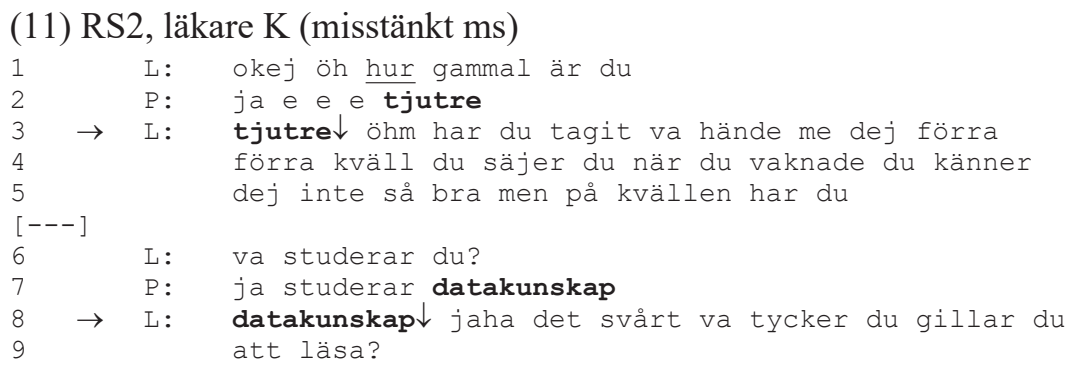

Att läkarna på detta sätt visar sin förståelse och därmed skapar trygghet hos patienten ser vi som ett uttryck för interaktionell kompetens. Repetitioner i funktionen bekräftelse förekommer oftare och hos fler av läkarna i RS2.

\section{Repetition som begäran om förtydligande (kategori 3)}

Prosodin spelar stor roll för hur repetitionerna tolkas, enligt Schegloff (1987). Här ska tilläggas att icke-verbala signaler, som vi inte haft möjlighet att dokumentera, sannolikt också spelar en viktig roll för patienternas tolkning i situationen, och det är ett viktigt skäl till att vi valt att basera vår kategorisering på patienternas reaktioner.

En repetition som sägs med frågetonfall kan tolkas som en implicit begäran om förtydligande (Andersson 2010). Det är en typ av reparation som till exempel Kitzinger (2014) kallar »repeat repair initiator». Ett sådant exempel är (12).

(12) RS1, läkare M (panikångest)

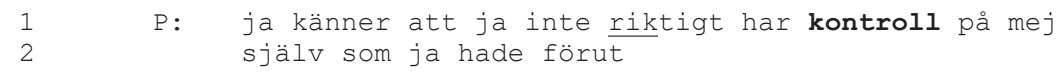


$\begin{aligned} & \rightarrow \quad \text { L: } \text { kontroll个 } \\ & \text { P: } \text { nä ja har lite dålig impulskontroll ja vill bli arg } \\ & \text { också }\end{aligned}$

I (12) upprepar L kontroll $\uparrow$ med stigton (rad 3) från P:s föregående tur. P ger ett förtydligande svar: nä ja har lite dålig impulskontroll och fortsätter turen med en utveckling av topiken: ja vill bli arg också. I de följande tre sekvenserna i (13) förstärks repetitionernas funktion som begäran om förtydligande av att L med sina repetitioner också ger uttryck för förvåning/misstro (jfr Norrick 1987).

(13) RS1, läkare L (tarmproblem)

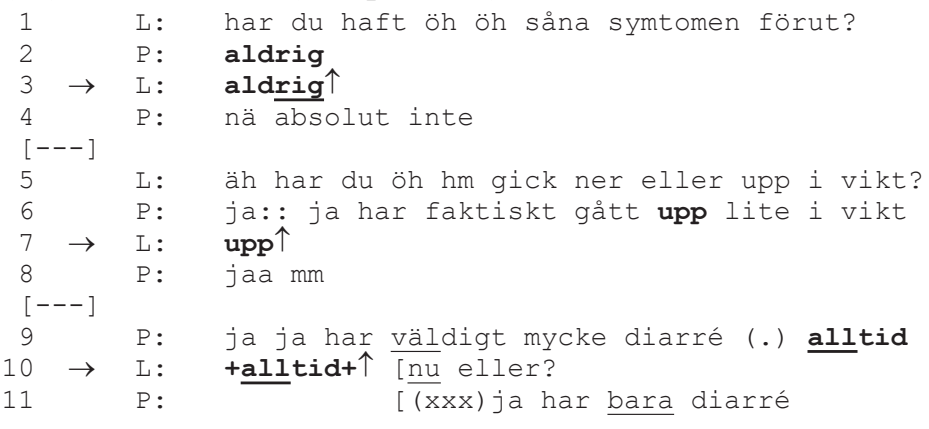

Repetitionerna, som uttalas med stigton i (13), fungerar som fokuserade kontrollfrågor (Lindholm 2003), exempelvis upp $\uparrow(\operatorname{rad} 7)$, som följer efter P:s svar på frågan om sin vikt, ja:: ja har faktiskt gått upp lite $i$ vikt ( $\operatorname{rad} 6)$ - ett svar som möjligen är anmärkningsvärt med tanke på P:s övriga symtom. Att repetitionerna kan tolkas som ett ifrågasättande av P:s svar gäller även L:s repetitioner av P:s extremfallsformuleringar ${ }^{13}$ aldrig $\uparrow(\operatorname{rad} 3)$ samt alltid $\uparrow(\operatorname{rad} 10)$, som uttalas med stark röstvolym. I samma tur begär L förtydligande också med den påföljande frågan $\underline{n u}$ eller? .

En repetition med funktionen begäran om förtydligande kan också tolkas som ett metaspråkligt reparationsinitiativ, det vill säga signalera att den talande inte förstått innebörden i ett ord (jfr Wong 2000). Så är troligtvis fallet med do::mnat $\uparrow \mathrm{i}(14)$.

(14) RS2, läkare D (stroke)

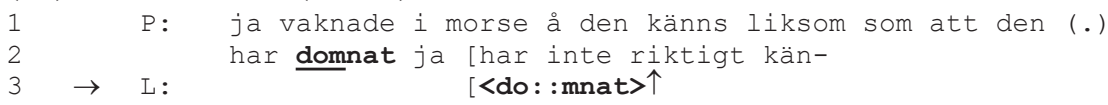

${ }^{13}$ Eng: extreme case formulations (Pomerantz 1986). 


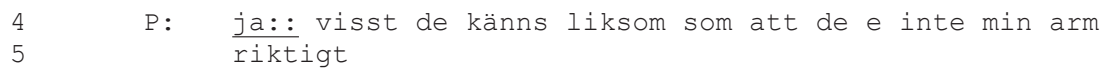

I (14), i RS2, uttalar L repetitionen do::mnat $\uparrow(\operatorname{rad} 3)$ på ett markerat sätt, långsamt med förlängt vokalljud på den första stavelsen och med stigton. I detta fall leder det till att $\mathrm{P}$ ger en utbyggd förklaring ( $\operatorname{rad} 4-5)$. Samma läkare (D) repeterar samma ord, domnat, i RS 1, och då framförs det på ett prosodiskt mindre markerat sätt.

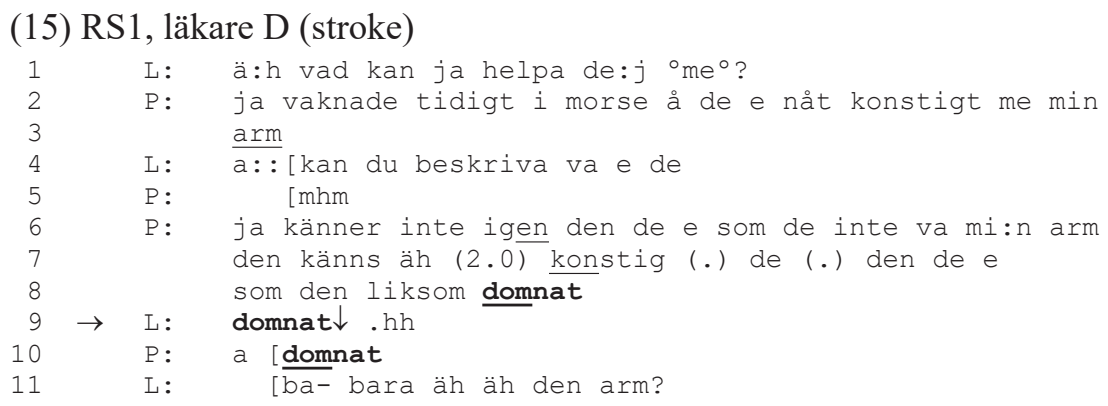

I det här fallet (15) upprepar L domnat med fallande ton, följt av en inandning. Här verkar L inte signalera att hen inte förstått ordet. P gör tolkningen att det är fråga om ett hörbarhetsproblem och ger respons bara i form av en bekräftelse: [j] a domnat ( $\operatorname{rad} 10)$, vilket tyder på att $\mathrm{P}: \mathrm{s}$ tolkning i situationen är att $\mathrm{L}$ är osäker på vad $\mathrm{P}$ har sagt, inte på ordets innebörd. L tar inte något nytt reparationsinitiativ utan fortsätter i nästa tur ( $\operatorname{rad} 11)$ med en ny fråga (bara äh äh den arm?) som delvis överlappar P:s svar på rad 10.

I (16), i RS2, indikerar L:s repetition dom vill? ( $\operatorname{rad} 5)$ att någonting är problematiskt i P:s föregående påstående dom vill åat mej på olika sätt ( $\operatorname{rad} 3-4)$.

(16) RS2, läkare I (paranoia)

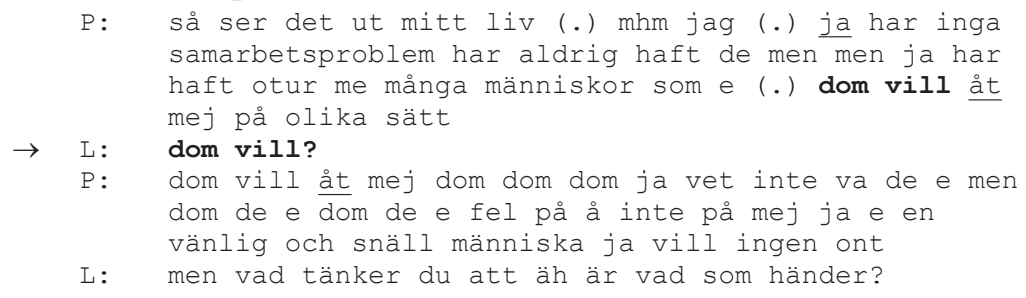

Repetitionen av den inledande delen av P:s yttrande (dom vill?) i (16) kan tolkas som en så kallad lucklämnande fråga, det vill säga »ofullbordade yttran- 
den [...] som kan uppfattas som avsiktligt avbrutna i syfte att vädja till motparten att fylla i ett eller flera ('förlösande') ord» (Linell \& Gustavsson 1987 s. 34). P uttrycker sig delvis osammanhängande i sin första tur, vilket gör att det är oklart om L:s repetition ska tolkas som metaspråkligt reparationsinitiativ (och i så fall skulle kunna signalera att partikelverbet vill åt är obekant för L). Repetitionen leder i alla fall till att $\mathrm{P}$ svarar med ett förtydligande (rad 6-8), ett utbyggt om än tämligen oklart sådant. L fortsätter med ett nytt initiativ ( $\operatorname{rad} 9$ ), en fokuserad frågeordsfråga (men vad tänker du att äh är vad som händer?).

Repetitioner som innebär en begäran om förtydligande kan ibland tolkas som en begäran om utveckling, alltså som en fortsättningssignal som uppmuntrar samtalspartnern att utveckla en topik eller en viss aspekt av det nyss sagda. En sådan kännetecknas (i engelskan) av fallande intonation och av att den inte är betonad, enligt Norrick (1987). Ett exempel med fallande intonation är repetitionen $\arg \downarrow(\operatorname{rad} 3)$, i (17) från RS1. Men repetitioner i rollspelen med denna funktion kan också uttalas med stigton, vilket visas i (19) nedan.

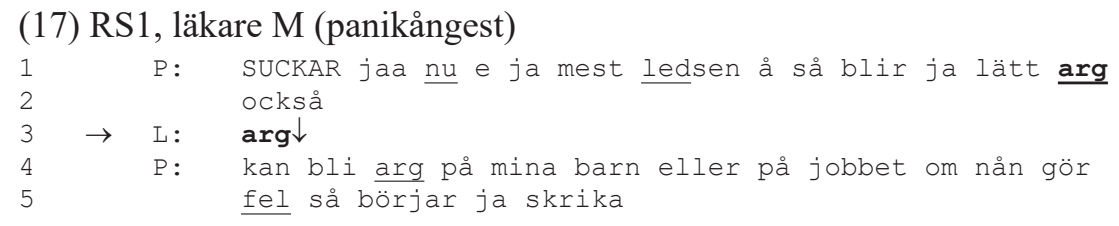

Exempel med fallande intonation finns även i (18) från RS2, där L:s repetition av lärare $\downarrow$ ( $\mathrm{rad} 3$ ) fungerar som en fortsättningssignal på samma sätt som i (17). Intrycket av att det är en fortsättningssignal förstärks av den lägre röstvolymen.

(18) RS2 läkare E (migrän)

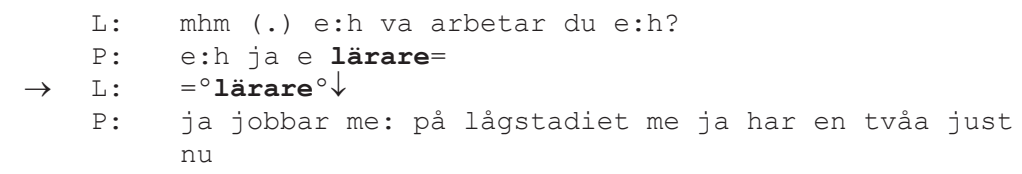

I (19), där L använder stigton, fungerar repetitionerna bakåtsyftande, det vill säga som ett sökande efter bekräftelse på att $\mathrm{L}$ hört rätt: $\mathrm{P}$ svarar bekräftande (ja::) i båda svarsturerna $(\operatorname{rad} 5$ och 8$)$. Men repetitionen fungerar också framåtsyftande, som en fortsättningssignal. På L:s upprepning tungt $\uparrow(\operatorname{rad} 4) \operatorname{ger} \mathrm{P}$ ett vagt svar (ja:: på nåt sätt) och fortsätter turen med en utveckling av topiken: 
åsså känner ja mej (.) väldit trött också ( $\operatorname{rad} 5-6)$. På sin upprepning väldigt trött $\uparrow(\operatorname{rad} 7)$ får L ett preciserande svar: ja:: å sådär som om ja inte har sovit nånting $(\mathrm{rad} 8)$.

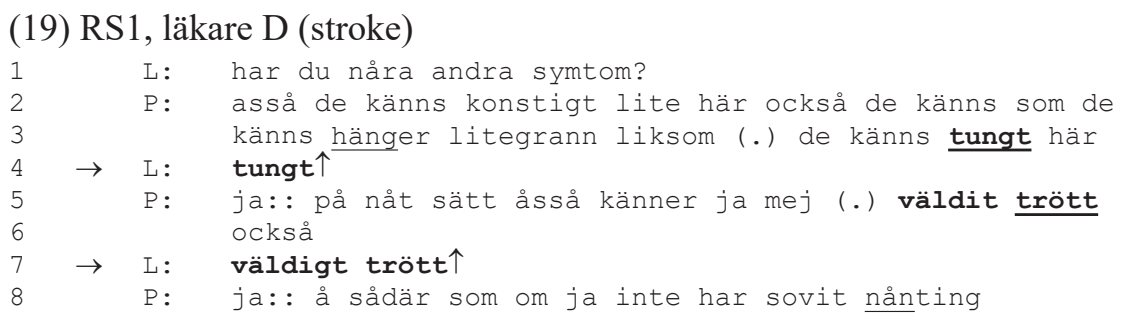

En annan läkare i RS1 (20) som repeterar ordet tung uttalar det svagt och utan stigton ( $\operatorname{rad} 4)$. P:s svar, ja åsså har ja ibland svårt å andas ( $\operatorname{rad} 5)$, visar att även en repetition som uttalas utan stigton kan fungera både bakåtsyftande och som en fortsättningssignal.

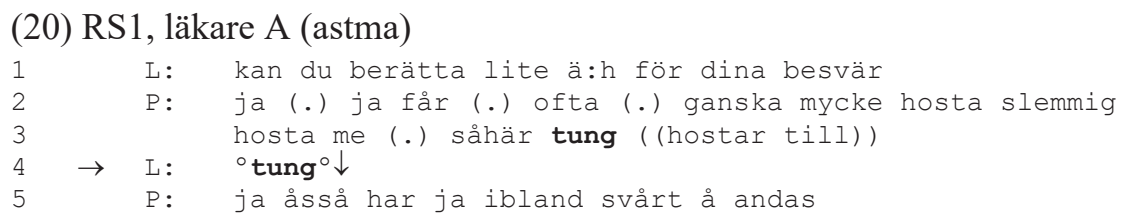

Utifrån rollspelsexemplen på repetitioner i kategori 3, begäran om förtydligande, kan vi inte påstå att intonationen är avgörande för hur repetitioner tolkas $\mathrm{i}$ interaktionen med dessa inlärare av svenska. En slutsats av hur repetitionerna bemöts av patienterna är att fallande intonation inte är nödvändig för att repetitionen ska tolkas som fortsättningssignal. Eventuellt bidrar uttalet med svag röst till att det uppfattas som fortsättningssignal, vilket (18) och (20) tyder på, men som nämndes inledningsvis i detta avsnitt spelar icke-verbala signaler sannolikt också en viktig roll för patienternas tolkning i situationen.

När det gäller kategori 3 är det svårare att peka på någon tydlig utvecklingstendens än vad som är fallet med de båda andra kategorierna. En viss tendens till en kvalitativ förändring är att läkarnas begäran om förtydligande oftare leder till mer utbyggda svar hos patienterna i RS2, möjligen beroende på att repetitionerna framförs med större säkerhet vid det andra rollspelstillfället. Exempel på detta finns i (14) och (16).

Begäran om förtydligande är den kategori som inrymmer flest förekomster. De allra flesta finns i RS1, och kanske är det en effekt av att läkarna har större 
behov av förtydliganden vid det första tillfället. Men i RS1 finns också exemplet med läkaren som tydligt ifrågasätter patientens extremfallsformuleringar (13), vilket inte tyder på osäkerhet hos läkaren utan tvärtom visar att läkaren besitter interaktionell kompetens redan vid denna tidpunkt. En övergripande slutsats om användningen av repetitioner i kategori 3 är ändå att det kan vara ett samtalsstrategiskt relativt enkelt (och för läkarna på förstaspråket möjligtvis väletablerat) sätt att föra läkare-patientsamtalet framåt.

\section{Sammanfattande diskussion}

På ett övergripande plan kan vi utifrån vår kvantitativa analys konstatera att läkarna vid det andra rollspelstillfället generellt har längre turer, talar mer och snabbare och använder färre tvekljud än vid det första tillfället. Det ser vi som tecken på utveckling av deltagarnas språkkunskaper och språkfärdigheter, även om det också måste tas med i beräkningen att det faktum att samma patient återkommer till en och samma läkare med samma symtom skapar en annan trygghet för läkaren den andra gången.

Den kvalitativa analysen pekar mot att även den interaktionella kompetensen hos läkarna har ökat. Samtalsmönstret för hur frågor och följdfrågor ställs redan i RS1 liknar det som påvisats i studier av autentiska läkare-patientsamtal, men läkarnas förmåga att ställa följdfrågor som mer direkt anknyter till patientens problembeskrivning ökar i RS2. Läkarna demonstrerar också sin förståelse för vad patienten har uppgett på ett tydligare sätt i RS2, till exempel genom att repetera centrala innehållsord från patientens problembeskrivningar i sina följdfrågor. Detta mer direkta sätt att följa upp patientens yttranden tolkar vi som ett uttryck för mer utvecklad interaktionell kompetens.

Bruket av repetitioner kan förenkla interaktionen för talaren genom att det ger lite extra betänketid - antalet förekomster är också flest i RS1 - men det står klart att läkarna använder repetitioner som en flerfunktionell resurs i rollspelen. Det står också klart att användningsmönstret förändras från RS1 till RS2. En skillnad visar sig i ekorepetitionerna, där talaren förefaller tänka högt eller processa något som nyss yttrats på liknande sätt som i en klassrumssituation. Sådana repetitioner förekommer bara i RS1. En annan skillnad är att repetition som begäran om förtydligande, det vill säga som ett reparationsinitiativ, tycks leda till mer utvecklade responser hos patienten i RS2. Detta ser vi som ett uttryck för ökad interaktionell kompetens, och detsamma gäller för re- 
petition som bekräftelse på ett centralt ord i patientens yttrande. Sådana förtroendeskapande kvittenser ges betydligt oftare och av fler läkare i RS2. Resultatet har beröringspunkter med Berbyuk Lindström (2008), som finner att icke-svenska läkare (»non-Swedes») använder repetitioner och omformuleringar som feedback mer intensivt än sina modersmålstalande kolleger. Dock visade Berbyuk Lindströms studie på en delvis motsatt tendens, nämligen att de som använde denna typ av feedback var de läkare som varit kortast tid i Sverige.

Den kvalitativa analysen visar hur samtalen byggs upp i relation till den pågående verksamheten. Sammantaget ger det en bild av att det skett en utveckling av läkarnas interaktionella kompetens vid det andra rollspelstillfället, men som Waring (2018) och andra påpekat måste slutsatser av det här slaget göras med viss försiktighet. Det longitudinella upplägget ger vissa möjligheter till jämförelser, men de kan aldrig bli helt rättvisande, på grund av svårigheten att urskilja vad som är ett resultat av utveckling och vad som beror på skillnader $\mathrm{i}$ den situationella kontexten. Idealt skulle vi därför ha arrangerat rollspel vid fler än två tillfällen (men det skulle ha krävt mer utrymme under kursens gång än dess föreståndare var intresserad av att ge oss). Här utgör emellertid deltagarperspektivet en viktig analytisk resurs. Samtalspartnerns reaktioner och responser är viktiga redskap för att avgöra vilka sociala handlingar som utförs och hur gemensam förståelse förhandlas fram. Genom de samtalandes tolkningar görs fortlöpande en värdering av den andra partens samtalsbidrag. Därmed sker »på plats» en indirekt värdering av andraspråkstalarens kompetens.

Som teoretiskt perspektiv bidrar begreppet interaktionell kompetens med värdefull kunskap om utvecklingen av ett andraspråk och i vår studie har detta perspektiv väckt intressanta frågor om hur förmågan att utföra sociala handlingar i interaktion utvecklas i relation till allmänna språkkunskaper och språkfärdigheter. Vi har kunnat se hur strukturellt enkla yttranden i form av repetitioner fyller viktiga funktioner i interaktionen. Att formulera sådana yttranden ställer relativt låga krav på språkkunskaper, däremot kräver det förmåga till situationell anpassning. Att läkarna klarar detta redan i RS1 kan förklaras av deras tidigare erfarenheter av anamnessamtal. Det kan också tyda på att förmågan att delta i och organisera sekventiella praktiker, såsom att hantera turtagning och reparationer, i viss mån är överförbart från förstaspråket (jfr Markee 2008).

Att demonstrera sin förståelse för vad samtalspartnern har sagt är en värdefull kompetens för andraspråkstalare (Markee 2000), inte minst som den professionella parten i institutionella samtal, där det kan finnas en oro hos lekmannen för att inte bli förstådd. Vi menar att det är en aspekt som är viktig att lyfta 
fram i språkutbildningar som syftar till att lära ut ett yrkesspråk (jfr Tykesson \& Kahlin 2014). Det finns en stor pedagogisk potential i att använda (inspelade) rollspel för reflektion och feedback till deltagarna om interaktionell kompetens. Rollspel är också, menar vi, en metod som stimulerar utvecklingen av interaktionell kompetens, då det är en interaktionsform där deltagarna behöver samordna olika språkliga resurser för att klara av att tala och lyssna simultant. Problemet med rollspelets hybriditet kvarstår dock.

I vårt upplägg prövade vi att minska hybriditeten genom att en av oss enbart agerade patient medan den andra var tillgänglig för språkstöd. Upplägget med denna tydligt markerade ram fungerade som vi avsett, genom att språkfrågor inte tog fokus från det fingerade patientmötet och läkarna generellt höll sig till sin professionella roll. Men det fanns vissa situationer när läkarna klev ur läkarrollen och därmed synliggjorde rollspelets hybriditet. Exempelvis är läkarens självreparation $d u d u$ sag? du såg? du sag? i (1) ett tecken på att deltagarna kan uppfatta rollspelet som ett övningstillfälle i viss mån. Detsamma gäller som nämnts eventuellt också repetitioner i kategorin ekorepetitioner. Givet det faktum att rollspelen arrangerades i en lektionssal på en språkkurs kan vi inte heller utesluta att läkarna primärt kanske inte såg sig själva i sin professionella roll utan som elever.

Läkarnas dialoger med bisittaren kopplat till det fortsatta anamnessamtalet är intressanta att analysera ur ett pedagogiskt perspektiv, liksom för övrigt de kommentarer som rollspelarna och åhörarna gör efter rollspelen, vilket vi över huvud taget inte har gått in på. Vi har här valt att hålla fokus på läkarnas yrkesspråkande.

En kritik som kan anföras mot rollspel som metod för utveckling av interaktionell kompetens är att samtal med patienter i autentiska situationer har ett syfte som inte går återskapa i rollspel (jfr Nguyen 2012). I rollspel är det inte »skarpt läge» och läkarna har heller inte möjlighet att använda sina erfarenheter fullt ut. Bland annat kan de inte utnyttja multimodala resurser som fysisk undersökning av patienterna. Men trots den konstruerade situationen visade sig läkarna lägga ner kraft på att formulera frågor på sätt som var tillräckliga för att driva samtalen framåt. Läkarnas erfarenhet av verkliga anamnessamtal var troligen den främsta anledningen till att rollspelen gick att genomföra redan efter fem veckors svenskundervisning och med övningar i spontant samtalande bara i blygsam omfattning. 


\section{Litteratur}

Andersson, Helena, 2010: Interkulturell kommunikation på ett svenskt sjukhus. Fallstudier av andraspråkstalare i arbetslivet. Uppsala: Institutionen för nordiska språk, Uppsala universitet.

Anward, Jan, 2000: Allt du önskar kan du få? Om SAG och talspråket. I: Språk och stil NF 10. S. 197-220.

Anward, Jan, 2004: Lexeme recycled. How categories emerge from interaction. I: Logos and Language 5:2. S. 31-46.

Bachman, Lyle F. \& Palmer, Adrian S., 1996: Language testing in practice: Designing and developing useful language tests (vol. 1). Oxford: Oxford University Press.

Berbyuk Lindström, Nataliya, 2008: Intercultural communication in health care: non-Swedish physicians in Sweden. Göteborg: Göteborgs universitet.

Berger, Evelyne \& Pekarek Doehler, Simona, 2018: Tracking change over time in storytelling practices: A longitudinal study of second language talk-in-interaction. I: S. Pekarek Doehler, J. Wagner \& E. González-Martínez (red.): Longitudinal studies on the organization of social interaction. London: Palgrave Macmillan. S. $67-102$.

Boyd, Elizabeth \& Heritage, John, 2005: Taking the history: questioning during comprehensive history-taking. I: J. Heritage \& D. W. Maynard (red.): Communication in medical care: interaction between primary care physicians and patients. Cambridge: Cambridge University Press. S. 151-184.

Cekaite, Asta, 2007: A child's development of interactional competence in a Swedish L2 classroom. I: The Modern Language Journal 91:1. S. 45-62.

Hall, Joan Kelly, 2018: From L2 interactional competence to L2 interactional repertoires: Reconceptualising the objects of L2 learning. I: Classroom Discourse 8:1. S. 25-39.

Hall, Joan Kelly \& Doehler, Simona Pekarek, 2011: L2 interactional competence and development. I: J. Kelly Hall, J. Hellermann \& S. Pekarek Doehler (red.): L2 interactional competence and development. Bristol: Multilingual Matters. S. 1-19.

Heritage, John, 1984: Garfinkel and ethnomethodology. Cambridge: Polity.

Heritage, John, 2010: Questioning in medicine. I: A. F. Freed \& S. Ehrlich (red.): "Why do you ask": The function of questions in institutional discourse. New York: Oxford University Press. S. 42-68.

Heritage, John \& Maynard, Douglas W. (red.), 2005: Communication in medical care: interaction between primary care physicians and patients. Cambridge: Cambridge University Press.

Houtkoop-Steenstra, Hanneke, 2000: Interaction and the standardized survey interview - the living questionnaire. Cambridge: Cambridge University Press.

Håkansson, Gisela \& Norrby, Catrin, 2010: Environmental influence on language acquisition. Comparing second and foreign language acquisition of Swedish. I: Language Learning 60:3. S. 628-650.

Joyner, Beres \& Young, Louise, 2006: Teaching medical students using role-play: Twelve tips for successful role-plays. I: Medical Teacher 28:3. S. 225-229. 
Kasper, Gabriele, 2000: Data collection in pragmatics research. I: H. Spencer-Oatey (red.): Culturally speaking: managing rapport in talk across cultures. London: Cassell. S. 316-341.

Kasper, Gabriele, 2006: Beyond repair: Conversation analysis as an approach to SLA. I: AILA Review 19. S. 83-99.

Kitzinger, Celia, 2014: Repair. I: J. Sidnell \& T. Stivers (red.): The handbook of conversation analysis. Oxford: Wiley-Blackwell. S. 229-256.

Landqvist, Mats, 2010: Samspel i rådgivningssamtal. I: A.-C. Edlund \& I. Mellenius (red.): Svenskans beskrivning 31. Umeå: Institutionen för språkstudier, Umeå universitet. S. 182-192.

Levy Scherrer, Paula \& Lindemalm, Karl, 2007: Rivstart: svenska som främmande språk. A1 + A2. Stockholm: Natur och kultur.

Levy Scherrer, Paula \& Lindemalm, Karl, 2009: Rivstart: svenska som främmande språk. B1 + B2. Stockholm: Natur \& kultur.

Lindholm, Camilla, 2003: Frågor i praktiken: flerledade frågeturer i läkare-patientsamtal. Helsingfors: Svenska litteratursällskapet i Finland.

Lindström, Jan, 2008: Tur och ordning: introduktion till svensk samtalsgrammatik. Stockholm: Norstedts akademiska förlag.

Linell, Per \& Gustavsson, Lennart, 1987: Initiativ och respons: om dialogens dynamik, dominans och koherens. Linköping: Linköpings universitet.

Linell, Per \& Persson Thunqvist, Daniel, 2003: Moving in and out of framings: activity contexts in talks with young unemployed people within a training project. I: Journal of Pragmatics 35:3. S. 409-434.

Luttenberger, Katharina, Grässel, Elmar, Simon, Cosima \& Donath, Carolin, 2014: From board to bedside - training the communication competences of medical students with role plays. I: Medical Education 14. S. 135-145.

Markee, Numa, 2000: Conversation analysis. Mahwah, N.J.: L. Erlbaum Associates.

Markee, Numa, 2008: Toward a learning behavior tracking methodology for CA-for-SLA. I: Applied Linguistics 29:3. S. 404-427.

Markee, Numa \& Kunitz, Silvia, 2013: Doing planning and task performance in second language acquisition: An ethnomethodological respecification. I: Language Learning 63:4. S. 629-664.

McNamara, Tim, 1997: 'Interaction' in second language performance assessment: Whose performance? I: Applied Linguistics 18. S. 446-466.

Melander, Helen \& Sahlström, Fritjof, 2011: Process eller produkt? Om samtalsanalysens möjligheter att studera lärande i interaktion. I: R. Säljö (red.): Lärande och minnande: som social praktik. Stockholm: Norstedts. S. 287-316.

Nestel, Debra \& Tierney, Tanya, 2007: Role-play for medical students learning about communication: Guidelines for maximising benefits. BMC Medical Education 2007, 7:3.

Nguyen, Hanh thi, 2012: Developing interactional competence: A conversation-analytic study of patient consultations in pharmacy. Houndmills, Basingstoke, Hampshire: Palgrave Macmillan.

Norrick, Neal, 1987: Functions of repetition in conversation. I: Text 7. S. 245-264.

Pekarek Doehler, Simona \& Petitjean, Cecile, 2017: Introduction: Interactional competences in institutional settings - Young people between school and work. I: S. Peka- 
rek Doehler, A. Bangerter, G. de Weck, L. Filliettaz, E. González-Martínez \& C. Petitjean (red.): Interactional competences in institutional settings: from school to the workplace. Cham: Palgrave Macmillan. S. 1-28.

Pekarek Doehler, Simona, Wagner, Johannes \& González-Martínez, Esther (red.), 2018: Longitudinal studies on the organization of social interaction. London: Palgrave Macmillan.

Pill, John \& McNamara, Tim, 2016: How much is enough? Involving occupational experts in setting standards on a specific-purpose language test for health professionals. I: Language Testing 33:2. S. 217-234.

Pomerantz, Anita, 1986: Extreme case formulations: a way of legitimizing claims. I: Human Studies 9. S. 219-229.

Sacks, Harvey, 1992: Lectures on conversation. Oxford: Blackwell Publishers.

Sacks, Harvey, Schegloff, Emanuel A. \& Jefferson, Gail A, 1974: A simplest systematics for the organization of turn-taking for conversation. I: Language 50. S. 696-735.

Sahlström, Fritjof, 2011: Learning as social action. I: J. Kelly Hall, J. Hellermann \& S. Pekarek Doehler (red.): L2 interactional competence and development. Bristol: Multilingual Matters. S. 45-66.

Schegloff, Emanuel A., 1987: Recycled turn beginnings: A precise mechanism in conversation's turn-taking organization. I: G. Button \& J. Lee (red.): Talk and social organization. Clevedon, England: Multilingual Matters. S. 70-100.

Schegloff, Emanuel A., 1996: Confirming allusions: Toward an empirical account of action. I: American Journal of Sociology 102:1. S. 161-216.

Socialstyrelsen, 2015: Nationella planeringsstödet 2015 - Tillgång och efterfrågan på vissa personalgrupper inom hälso- och sjukvård samt tandvård. Stockholm: Socialstyrelsen. http://www.shvab.se/Documents/Nationella\%20planeringsstödet.pdf

Socialstyrelsen, 2018a: Nationella planeringsstödet 2018. Bedömning av tillgång och efterfrågan på vissa personalgrupper inom hälso- och sjukvård samt tandvård. Stockholm: Socialstyrelsen. https://www.socialstyrelsen.se/globalassets/sharepointdokument/artikelkatalog/statistik/2018-2-23.pdf

Socialstyrelsen, 2018b: https://legitimation.socialstyrelsen.se/sv/utbildad-inom-eu-ellerees/lakare/ansok-om-legitimation.

Tannen, Deborah, 1989: Talking voices: repetition, dialogue, and imaginary in conversational discourse. Cambridge: Cambridge University Press.

Thomassen, Gøril, 2005: Den flerbunnete treningssamtalen: en studie av samtaler mellom pasient og student fra sykepleier- og medisinerutdanning. Trondheim: NTNU.

Tykesson, Ingela \& Kahlin, Linda, 2014: Att ge eller inte ge återkoppling: moldavisk callcenterpersonal i dialog med svenska uppringare. I: Nordand: nordisk tidsskrift for andrespråksforskning 9:1. S. 89-115.

Wagner, Johannes, Pekarek Doehler, Simona \& González-Martínez, Esther, 2018: Longitudinal research on the organization of social interaction: Current developments and methodological challenges. I: S. Pekarek Doehler, J. Wagner \& E. González-Martínez (red.): Longitudinal studies on the organization of social interaction. London: Palgrave Macmillan. S. 3-35.

Waring, Hansun Zhang, 2018: Teaching L2 interactional competence: problems and possibilities. I: Classroom Discourse 9:1. S. 57-67. 


\section{I. Tykesson, L. Kahlin \& M. O. Romanitan}

Wette, Rosemary, 2011: English proficiency tests and communication skills training for overseas-qualified health professionals in Australia and New Zealand. I: Language Assessment Quarterly 8:2. S. 200-210.

Wong, Jean, 2000: Repetition in conversation: A look at "First and Second Sayings". I: Research on Language and Social Interaction 33:4. S. 407-424.

Woodward-Kron, Robyn \& Elder, Catherine, 2016: A comparative discourse study of simulated clinical roleplays in two assessment contexts: Validating a specific-purpose language test. I: Language Testing 33:2. S. 251-270.

Young, Richard F., 2011: Interactional competence in language learning, teaching, and testing. I: E. Hinkel (red.): Handbook of research in second language teaching and learning (vol. 2). New York: Routledge. S. 426-443.

Young, Richard F. \& Miller, Elizabeth R., 2004: Learning as changing participation: Discourse roles in ESL writing conferences. I: The Modern Language Journal 88:4. S. $519-535$.

\section{Transkriptionsnyckel}

\begin{tabular}{|c|c|}
\hline [---] & En eller flera rader utlämnade \\
\hline$\rightarrow$ & Markerar aktuell analysenhet, t.ex. initierad reparation \\
\hline (.) & Kort men märkbar paus, »mikropaus» \\
\hline (1.4) & Paus i tiondels sekunder \\
\hline 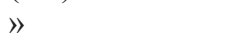 & Turen fortsätter på ny rad \\
\hline$=$ & Sammanhängande turer utan hörbart uppehåll \\
\hline $\mathrm{tt}-$ & Avbrutet ord \\
\hline & Förlängning av vokal \\
\hline ja: & Ytterligare förlängning av vokal \\
\hline övriga & Emfatiskt tryck \\
\hline${ }^{\circ} \mathrm{okej}^{\circ}$ & Sägs med svag röststyrka \\
\hline+ aldrig+ & Sägs med stark röststyrka \\
\hline & Ordet sägs med markant stigande intonation \\
\hline$\downarrow$ & Ordet sägs med fallande intonation \\
\hline jaså? & Yttrandet sägs med frågeintonation \\
\hline $\begin{array}{l}<\text { ord ord ord }> \\
((\text { hostar }))\end{array}$ & $\begin{array}{l}\text { Långsammare tal än det omgivande talet } \\
\text { Icke-verbala aspekter eller kommentarer till aktiviteter }\end{array}$ \\
\hline $\begin{array}{l}\text { P: på [höger sida } \\
\text { L: [alltid? }\end{array}$ & Överlappande tal \\
\hline (de där) & Möjlig tolkning av svårhörbart tal \\
\hline & $\begin{array}{l}\text { Ohörbart (ett eller flera ord) } \\
\text { Inandning }\end{array}$ \\
\hline
\end{tabular}

